\title{
Correction to: High normal TSH is associated with lower mannan-binding lectin in women of childbearing age
}

Malgorzata Karbownik-Lewinska ${ }^{1,2^{*}}$, Jan Stepniak ${ }^{2}$, Magdalena Marcinkowska ${ }^{1}$, Adrian Krygier $^{3}$ and Andrzej Lewinski ${ }^{1,4}$

\section{Correction to: BMC Endocrine Disorders (2020) 20:1 https://doi.org/10.1186/s12902-019-0484-y}

In the original publication of this article [1] the first affiliation of the authors is incorrect, the correct affiliation of the first one is: Department of Endocrinology and Metabolic Diseases, Polish Mother's Memorial Hospital - Research Institute, Lodz, Poland.

\begin{abstract}
Author details
'Department of Endocrinology and Metabolic Diseases, Polish Mother's Memorial Hospital - Research Institute, Lodz, Poland. ${ }^{2}$ Department of Oncological Endocrinology, Medical University of Lodz, Lodz, Poland. ${ }^{3}$ Oxidative Stress Laboratory of the Center of Medical Laboratory Diagnostics and Screening, Polish Mother's Memorial Hospital -Research Institute, Lodz, Poland. ${ }^{4}$ Department of Endocrinology and Metabolic Diseases, Medical University of Lodz, Lodz, Poland.
\end{abstract}

Published online: 09 June 2020

\section{Reference}

1. Karbownik-Lewinska M, et al. High normal TSH is associated with lower mannan-binding lectin in women of childbearing age. BMC Endocr Disord. 2020;20:1. https://doi.org/10.1186/s12902-019-0484-y.

The original article can be found online at https://doi.org/10.1186/s12902019-0484-y.

* Correspondence: MKarbownik@hotmail.com

'Department of Endocrinology and Metabolic Diseases, Polish Mother's Memorial Hospital - Research Institute, Lodz, Poland

${ }^{2}$ Department of Oncological Endocrinology, Medical University of Lodz, Lodz, Poland

Full list of author information is available at the end of the article

(c) The Author(s). 2020 Open Access This article is licensed under a Creative Commons Attribution 4.0 International License, which permits use, sharing, adaptation, distribution and reproduction in any medium or format, as long as you give appropriate credit to the original author(s) and the source, provide a link to the Creative Commons licence, and indicate if changes were made. The images or other third party material in this article are included in the article's Creative Commons licence, unless indicated otherwise in a credit line to the material. If material is not included in the article's Creative Commons licence and your intended use is not permitted by statutory regulation or exceeds the permitted use, you will need to obtain permission directly from the copyright holder. To view a copy of this licence, visit http://creativecommons.org/licenses/by/4.0/ The Creative Commons Public Domain Dedication waiver (http://creativecommons.org/publicdomain/zero/1.0/) applies to the data made available in this article, unless otherwise stated in a credit line to the data. 